\title{
Relationship between parental autonomy support and academic motivation among junior high students
}

\author{
Syipa Husni Fadilah \\ Faculty of Psychology, Universitas Padjadjaran, Indonesia \\ Email: husnifadilah.shf@gmail.com \\ Afra Hafny Noer \\ Faculty of Psychology, Universitas Padjadjaran, Indonesia \\ Email: afra@unpad.ac.id \\ Surya Cahyadi \\ Faculty of Psychology, Universitas Padjadjaran, Indonesia \\ Email: surya@unpad.ac.id \\ Laila Qodariah \\ Faculty of Psychology, Universitas Padjadjaran, Indonesia \\ Email: Laila.qodariah@unpad.ac.id \\ Langgersari Elsari Novianti \\ Faculty of Psychology, Universitas Padjadjaran, Indonesia \\ Email: elsari@unpad.ac.id
}

(Received: 22-November-2019; Reviewed: 12-December-2019; Accepted: 20-December-2019; published: 26-December-2019)

\begin{abstract}
This study aims to observe the relationship between parental autonomy support and academic motivation among junior high students. This correlational study collected data from 124 students and their mothers. Convenience sampling was used. The instruments employed were Perceived Parental Autonomy Support Scale and Academic Self-Regulation Questionnaire. The Spearman's Rank was used for correlation analysis. The results revealed that parental autonomy support and maternal autonomy support has a positive correlation with students' autonomous motivation. The more frequently students receive support from parents and the more frequently mothers give support to their children, the higher motivation students have to perform activities they desire. Maternal autonomy support also associates positively with students' controlled motivation. The more often mothers give freedom, the higher motivation students have to do activities coming from internal and external pressures. Parental control perceived by students and maternal control have no link with overall motivation.
\end{abstract}

Keywords: Parental Autonomy Support; Autonomy Support; Controlling Parenting; Motivasi; Self-Determination.

\begin{abstract}
Abstrak: Penelitian bertujuan melihat hubungan antara parental autonomy support dengan motivasi pada siswa sekolah menengah pertama. Ini merupakan studi korelasional dengan subjek 124 siswa beserta ibunya. Teknik penarikan sampel menggunakan convenience sampling. Alat ukur yang digunakan yaitu Perceived Parental Autonomy Support Scale dan Academic Self-Regulation Questionnaire. Analisis uji korelasi dilakukan melalui uji Rank Spearman. Hasilnya menunjukkan bahwa autonomy support ibu dan ayah yang dirasakan siswa serta autonomy support yang diberikan ibu berhubungan positif dengan motivasi otonom siswa semakin sering siswa merasakan keleluasaan dari ibu dan ayahnya, serta semakin sering ibu memberikan keleluasaan, maka semakin tinggi dorongan siswa melakukan aktivitas karena keinginan dan pilihannya sendiri. Autonomy support yang diberikan ibu juga berhubungan positif dengan motivasi terkontrol siswa. Semakin sering ibu memberikan keleluasaan maka
\end{abstract}


semakin tinggi dorongan siswa melakukan aktivitas karena tekanan dari dalam dan luar dirinya. Kontrol ibu dan ayah yang dirasakan siswa serta kontrol yang diberikan ibu tidak berhubungan dengan semua bentuk motivasi.

Kata kunci: Parental Autonomy Support; Autonomy Support; Controlling Parenting; Motivasi; Self-Determination.

This is an open access article under the CC BY-NC 4.0 license

(http://creativecommons.org/licenses/by-nc-nd/4.0/).

\section{INTRODUCTION}

Parental autonomy support has been linked with positive teenage behaviors, but its association with cultures in collectivist groups is still vague (Pierre et al., 2017). Motivated students are more likely to do an activity wholeheartedly and yield better performance than unmotivated students. However, motivation may increase or decrease if students experience transition from elementary school to junior high school due to greater school shifts, more teachers, and higher demands for independent learning (Grolnick, 2009). Students have increasingly limited freedom to feel motivated in doing activities as a result of many demands and social roles that require students to be highly responsible for daunting tasks (Grolnick, 2009).

Motivation plays an important role in students' academic performance (Kusuma et al., 2018; Jiang et al., 2018; Luthans, Luthans, \& Chaffin, 2019; Zhang et al., 2018). According to Deci \& Ryan (2008) self-determination theory distinguishes between autonomous motivation and controlled motivation. Autonomous motivation refers to desires and choices that lead an individual to take certain actions. An autonomous-motivated individual thinks it is important for him or her to do a particular activity and feels pleasure when doing it.

Autonomous motivation and controlled motivation influence experience and performance qualities. Autonomous-motivated students tend to have greater conceptual understanding, better grades, and higher productivity (Deci \& Ryan, 2008). However, not all students perform academic activities due to autonomous motivation. Autonomy support facilitates motivated actions because they are autonomously determined. Meanwhile, competence and relatedness support can strengthen autonomous motivation only if all the supports are managed accordingly (Power \& Goodnough, 2019; Ahn, 2019; Martin, Kelly, \& Terry, 2018).

Parental autonomy support consists of two sub-dimensions: autonomy support and controlling parenting. Autonomy support is defined as parents' behavior that acknowledges a child's feelings, gives reasons for rules and demands, and provides options and opportunities to take initiatives. Controlling parenting, however, refers to parents' controlling behavior that resort to threats to give punishments, guilty criticism, and pressures to excel (Mageau et al., 2015). Empirical data show that autonomy support and controlling parenting form two different factors, so this construct should be measured separately (Mageau et al., 2015).

Some studies by Won \& Yu (2018); Devina, Savitri, \& Pandin (2018); Froiland \& Worrell (2017); Mageau et al. (2015); Abidin, Purboningsih, \& Novianti (2016) have shown that parental autonomy support can be utilized to improve students' time and academic management, but little research has been done into this area with Indonesians as the respondents. Thus, this study is conducted to examine the relationship between parental autonomy support and academic motivation among junior high students.

\section{METHODS}

The population of this correlational study was students in the eighth and ninth grades and their parents. Recruited using convenience sampling technique, a total of 124 students and their mothers took part in this study. Data were collected using two sets of questionnaires: 1) Academic Self-Regulation Questionnaire (SRQ- 
A) (Ryan \& Connell, 1989) that had been translated into Indonesian to measure student motivation and 2) Perceived Parental Autonomy Support Scale (P-PASS) by Mageau et al. (2015) that had been adapted by Abidin, Purboningsih, \& Novianti (2016) to measure parental autonomy support. SRQ-A consisted of 32 items divided into four subscales: external regulation (9 items), introjected regulation (9 items), identified regulation ( 7 items) and intrinsic motivation (7 items). SRQ-A used 4 point-Likert scale from 1 (not at all true) to 4 (very true).

SRQ-A assessment was performed through: 1) the Relative Autonomy Index (RAI) to observe the overall quality of motivation and 2) scores of both autonomous and controlled motivation. The SRQ-A reliability was 0.90 . On the other hand, P-PASS consisted of 24 items divided into two subscales: autonomy support (12 items) to measure autonomy support and psychological control (12 items) to measure controlling parenting. P-PASS employed a scale of 1(strongly disagree) to 7 (strongly agree). PPASS was comprised of two parts: the first part with students as the subjects (assessing fathers and mothers separately) and the second part with parents as the subjects. The P-PASS reliability was 0.75 for parents as the subjects, 0.79 for students as the subjects assessing mothers and 0.80 for students as the subjects assessing fathers.

Data were analyzed using frequency test, difference test and correlation test. Frequency test aimed to describe parental autonomy support and student motivation. Difference test was performed using Mann-Whitney test to find out the differences between autonomy support and controlling parenting. Correlation test was employed through Spearman's Rank test to look into the association between parental autonomy support (autonomy support and controlling parenting) and student motivation.

\section{RESULTS AND DISCUSSION}

Table 1. Description of Parental Autonomy Support

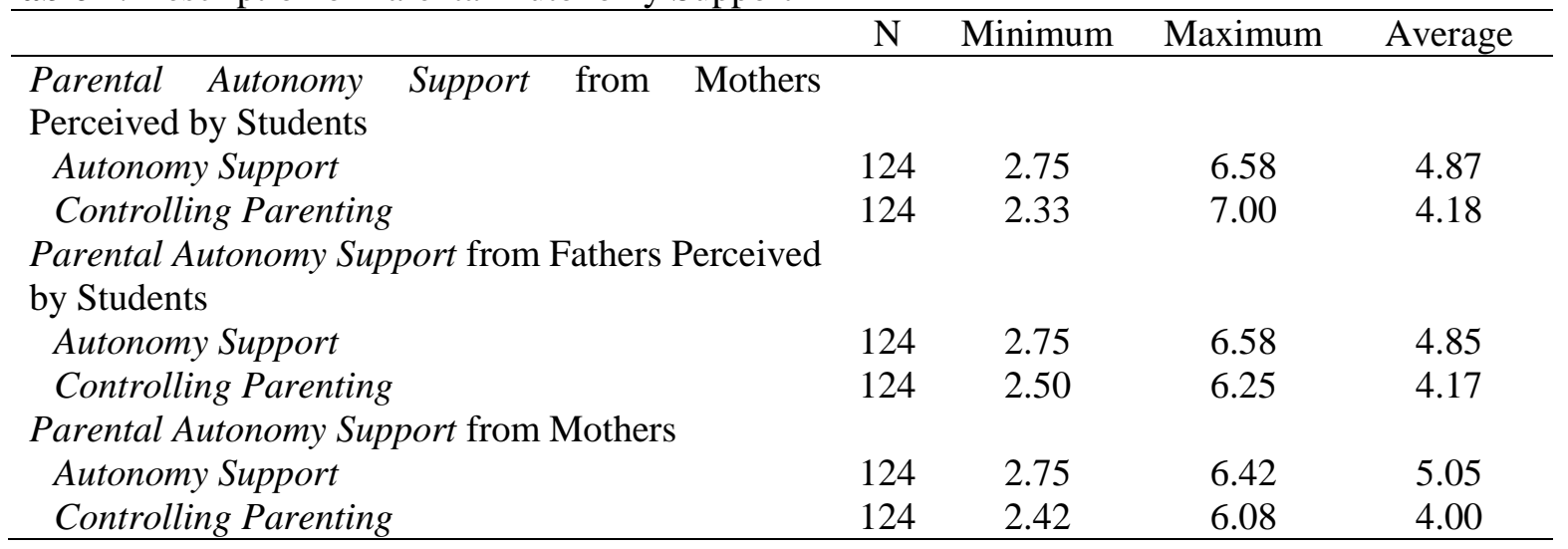

Table 1 shows that the average autonomy support values are higher than the average controlling values. Thus, the Mann-Whitney difference test was performed to observe the differences illustrated in Table 2.

Table 2. Difference Test on Autonomy Support with Controlling

\begin{tabular}{ll}
\hline & $Z$ \\
\hline Autonomy Support with Controlling from Mothers Perceived by Sudents & $-7.50^{*}$ \\
Autonomy Support with Controlling from Fathers Perceived by Students & $-6.88^{*}$ \\
Autonomy Support with Controlling from Mothers & $-10.19^{*}$ \\
\hline
\end{tabular}

Table 2 shows that autonomy support has greater values than controlling, meaning that both students and mothers assumed that parents provided more autonomy support than control. Mothers argued that they gave more freedom than control to their children. Students also claimed they received more freedom than control from their parents. This is in line with the study by Abidin, Purboningsih, \& Novianti (2016) that revealed parents controlled their 
children with autonomy supporting parenting, not parenting control. Parents explained the reasons they set the rules and demands for their children and gave opportunities and options to their children. Parents did not impose threats, guilty feelings, and pressures on their children in order to behave properly.

Table 3. Description of Student Motivation

\begin{tabular}{lcccc}
\hline & $\mathrm{N}$ & Minimum & Maximum & Average \\
\hline Relative Autonomy Index (RAI) & 135 & -4.63 & 2.49 & -0.63 \\
Autonomous Motivation & 135 & 2.14 & 4.00 & 3.23 \\
Controlled Motivation & 135 & 1.94 & 4.00 & 3.36 \\
\hline
\end{tabular}

It can be seen from Table 3 that the average RAI value is negative, signifying that the majority of students had low motivation level and were more likely to have controlled motivation. Most students engaged in academic activities due to both external and internal factors, not because of their own desires or choices. Demands, threats and rewards as well as pressures to avoid guilt and increase ego initiated students' willingness to perform academic activities. Since students do something to seek rewards, they are encouraged by controlled motivation.

Students were in the transition period from elementary school to secondary school. In this period, students were more vulnerable to lose autonomous motivation since the freedom to do desired activities was increasingly limited by the considerable amount of demands and social roles that require students to be responsible for ill-favored tasks (Grolnick, 2009). The average value of autonomous motivation and controlled motivation was $>2.5$, indicating that the majority of students had high autonomous motivation and controlled motivation. Most students carried out academic activities because of their own desires and choices as well as pressures from internal and external factors.

The finding regarding the high level of autonomous and controlled motivation is in accordance with previous studies, revealing that high school students did not show a purely autonomous profile, which was characterized by high autonomous motivation and low controlled motivation (Guay et al., 2013). The simultaneous emergence of controlled motivation and autonomous motivation during secondary school reflects the significant complexity of people's behaviors in which parents sometimes give freedom and control to ensure that students achieve educational goals (Guay et al., 2013).

Table 4. Correlation between Parental Autonomy Support and Student Motivation

\begin{tabular}{|c|c|c|c|}
\hline & $\begin{array}{c}\text { Relative } \\
\text { Autonomy } \\
\text { Index }\end{array}$ & $\begin{array}{c}\text { Autonomous } \\
\text { Motivation }\end{array}$ & $\begin{array}{l}\text { Controlled } \\
\text { Motivation } \\
\end{array}$ \\
\hline \multicolumn{4}{|l|}{ Autonomy Support } \\
\hline $\begin{array}{l}\text { Autonomy Support from } \\
\text { Perceived by Students }\end{array}$ & 0.033 & $0.198^{*}$ & 0.141 \\
\hline $\begin{array}{l}\text { Autonomy Support from Fathers Perceived } \\
\text { by Students }\end{array}$ & 0.092 & $0.229 *$ & 0.152 \\
\hline Autonomy Support Given by Mothers & -0.036 & $0.181^{*}$ & $0.207 *$ \\
\hline \multicolumn{4}{|l|}{ Controlling Parenting } \\
\hline $\begin{array}{l}\text { Controlling from Mothers Perceived by } \\
\text { Students }\end{array}$ & 0.101 & 0.059 & -0.015 \\
\hline $\begin{array}{l}\text { Controlling from Fathers Perceived by } \\
\text { Students }\end{array}$ & 0.082 & 0.116 & 0.051 \\
\hline Controlling Given by Mothers & -0.049 & -0.003 & 0.024 \\
\hline
\end{tabular}

As seen from Table 4, the value of the association between autonomy support and relative autonomy index is $p>0.05$, signifying that there is a significant relationship between autonomy support and relative autonomy index (overall motivation). The present study shows 
that both autonomy support from mothers and autonomy support from parents perceived by students have no link with the quality of overall motivation. Regardless of how often mothers give discretion to students and regardless of how frequent students receive discretion from parents, the quality of overall motivation is not affected. This is in line with the study by Marbell \& Grolnick (2013), revealing that autonomy support had no association with students' RAI, but has a positive association with students' autonomous motivation.

The relationship between autonomy support and autonomous motivation has $p$ value $<0.05$, meaning that autonomy support has a significant link with students' autonomous motivation. The correlation coefficient $r=0.198$ for autonomy support from mothers perceived by students, $r=0.229$ for autonomy support from fathers perceived by students and $r=0.181$ for autonomy support given by mothers. According to Dancey \& Reidy (2011), the value of $r$ between 0.1 and 0.3 indicates a weak relationship, while positive value means a positive relationship. All this suggests that autonomy support has a weak, but positive relationship with autonomous motivation.

Both autonomy support of parents perceived by students and autonomy support given by mothers have a positive relationship with students' autonomous motivation. This relationship suggests that the level of students' autonomous motivation is affected by how often students receive freedom from their parents and how often mothers give freedom to students. The more often students receive freedom from parents after being given explanation about the demands, being given opportunities and choices, and being accepted by parents, the higher motivation students have to start doing academic activities they desire. Likewise with the freedom given by mothers, the more often mothers give freedom to their children, the greater motivation students have to carry out academic activities because of their own desires and choices.

Students who receive freedom from parents do not feel constrained to do activities determined by their parents. Students have freedom to do activities as they wish, so they can freely choose activities according to their own desires and choices. The same result is also obtained by previous substantial research, finding that students who receive autonomy support tend to feel autonomous motivation in performing academic activities (Grolnick,
Friendly, \& Bellas, 2009). A study Li et al. (2018) also found that autonomy support is associated positively with autonomous motivation.

Table 4 shows that the relationship between autonomy support from mothers and controlled motivation has the value of $p>0.05$, suggesting that there is a significant relationship between autonomy support given by mothers and students' controlled motivation. The correlation coefficient $r=0.207$ was obtained, meaning that autonomy support from mothers has a weak, but positive relationship with controlled motivation. How frequent mothers give freedom to students affects the level of students' controlled motivation. The more often mothers give freedom to their children after explaining rules and demands, giving opportunities and choices as well as accepting children's feelings, the higher motivation students have to perform academic activities do to both internal and external pressures. This can be caused by the freedom students have to determine what they will do. When the pressure holds no importance for life, students tend to perform academic activities in order to avoid pressures. The presence of relationship between autonomy support from mothers and controlled motivation is in line with the results of the study by $\mathrm{Li}$ et al. (2018), revealing that autonomy support has a positive link with autonomous support.

Different from autonomous support from mothers, the relationship between autonomy support from parents perceived by students and controlled motivation obtained the value of $p>$ 0.05 , meaning that there is no significant relationship between autonomy support from parents perceived by students and controlled motivation. This relationship signifies that how often students is given freedom from their parents has no link with the level of motivation students have to carry out academic activities due to internal and external pressures. The freedom students feel when making decisions on activities they want to do is not associated with the level of controlled motivation they have.

The relationship between the controlling and the motivation has the $p$ value of $>0.05$ which means that there is an insignificant relation between the controlling and students' motivation. The controlling from the mother and that from the both parent toward students did not significantly promote students' motivation whether it is the overall motivation, the 
autonomous one, or the the controlled one. The frequency of the mother's or the both parent's controlling treatment toward students did not corelate with students' motivation. This condition is resemblance to the research conducted by Marbell \& Grolnick (2013) which states that parental control do not corelate with the autonomous and controlled motivation. On the other hand, that result contradicts the previous substantial study which claims that students experiencing parental control tend to have controlled motivation (Grolnick, Friendly $\&$ Bellas, 2009).

The absence of the relation between the controlling and students' motivation (whether it is the relative autonomy index or autonomous and controlled motivation) may be resulted from the respondents' culture, in which Indonesian's parents believe that the control toward the children is an essential element in parenting while it is also an obligatory that the children have to respect and obey them. It is a popular believe that the children will get a kind of carma or be damned if the do not live up to that expectation. (Riany, Meredith, \& Cuskelly, 2016). The children are accustomed to obey parental controls. Thus, it makes the controlling does not correspond with their academic motivation.

Table 5. Correlation between Motivation and Students' Score

\begin{tabular}{ll}
\hline & Score \\
\hline Relative Autonomy Index & 0.020 \\
\hline Autonomous Motivation & 0.116 \\
Controlled Motivation & 0.089 \\
\hline
\end{tabular}

Table 6. Correlation between Types of Motivation and Students' Score

\begin{tabular}{lc}
\hline & Score \\
\hline Autonomous Motivation & \\
Intrinsic Motivation & 0.021 \\
Identified Regulation & $0.226^{*}$ \\
\hline Controlled Motivation & \\
Introjected Regulation & 0.121 \\
External Regulation & 0.054 \\
\hline
\end{tabular}

The correlation between motivation and students' score is also observed in this study. As seen in Table 5, the $\mathrm{p}$ value from the correlation between the relative autonomy index, autonomous motivation, controlled motivation and students' motivation is $>0.05$, meaning that there is not any significant correlation between those three aspects and students' score. In doing their academic activities, students were driven by their own will, choices, and their internal or external pressure. That drive was not correlated with their score. However, a different $p$ value comes from the correlation between students' score and both autonomous and controlled motivation's types. It is shown in Table 6 that the correlation between the autonomous type (the identified regulation one) and students' score resulted in $\mathrm{p}$ value of $<0.05$ with the coefficient correlation of $r=0.226$. Thus, the identified regulation shows a positive correlation, even though it is weak, with students' performance. The higher students' motivation in doing an activity due to their realization of its importance, the higher their score is.

Students doing their activities due to realizing its importance and seeing beneficial outcomes will be likely to put an effort in doing the activities and involve themselves so that they achieve a high score. The correlation between the identified regulation and students' score is also explained by Guay et al. (2013) in which the identified regulation is stated to have a positive correlation with students' academic achievement seen from their academic transcript.

\section{CONCLUSION AND SUGGESTION}

This study found that in majority parents often gave their children freedom to have a chance and to choose, explanation about parents' demands, and opportunities to listen to 
students' feeling rather than to control students by giving them punishment threat, guiltytriggering critics, and pressures to have more achievement. It is shown that the autonomy support is not correlated with the quality of the motivation in a whole. Nevertheless, it has a positive correlation with the autonomous motivation. It means that the more students get a freedom from parents and the more mothers give them chances and choices, explanation of the rules, and accepting their feelings, the higher students' motivation in performing their academic activities due to their own choices.

The autonomy support from mothers also positively correlates with students' controlled motivation, in which the more mothers give freedom to children, the higher their motivation is in doing academic activities due to internal and external pressures and demands. The controlling parenting is not correlated with students' motivation. All of those points show that the controlling frequency from parents or mothers toward students is not correlated with their motivation.

There is a limitation to this study which should be noted. Although the majority of the respondents were Sundanese, there is not any sufficient explanation about this variable. Thus, a further Sundanese cultural background may become a consideration in the future study, especially in terms of its effects on parental autonomy support.

\section{REFERENCES}

Abidin, F. A., Purboningsih, E. R., \& Novianti, L. E. (2016). Model Perceived Parental Control pada Orangtua dan Remaja Usia 12-15 Tahun di Kota Bandung (Laporan Penelitian). Universitas Padjadjaran. Bandung.

Ahn, J. (2019). Role of harmonious and obsessive passions for autonomy, competence, and relatedness support with integrated resort experiences. Current Issues in Tourism, 1-14

Dancey, C. P., \& Reidy, J. (2011). Statistics Without Maths for Psychology (5th ed.). England: Pearson Education Limited.

Deci, E. L., \& Ryan, R. M. (2008). Facilitating Optimal Motivation and Psychological Well- Being Across Life' s Domains. Canadian Psychology, 49(1), 14-23. https://doi.org/10.1037/0708-5591.49.1.14
Devina, C., Savitri, J., \& Pandin, D. A. (2018). Pengaruh Parent Autonomy Support terhadap School Engagement pada Siswa Kelas IV-VI SD "X" di Kota Bandung. Humanitas (Jurnal Psikologi), 1(1).

Froiland, J. M., \& Worrell, F. C. (2017). Parental autonomy support, community feeling and student expectations as contributors to later achievement among adolescents. Educational Psychology, 37(3), 261-271.

Grolnick, W. S. (2009). The Role of Parents in Facilitating Autonomous Self-Regulation for Education. Theory and Research in Education, $\quad 7(2)$, 164-173. https://doi.org/10.1177/147787850910432 1

Grolnick, W. S., Friendly, R. W., \& Bellas, V. M. (2009). Parenting and Children's Motivation at School. In K. R. Wentzel \& A. Wigfield (Eds.), Handbook of Motivation at School. New York: Routledge.

Guay, F., Ratelle, C., Larose, S., Vallerand, R. J., \& Vitaro, F. (2013). The Number of Autonomy-Supportive Relationships: Are More Relationships Better for Motivation, Perceived Competence, and Achievement? Contemporary Educational Psychology, 38 375-382. https://doi.org/10.1016/j.cedpsych.2013.07 .005

Jiang, Y., Rosenzweig, E. Q., \& Gaspard, H. (2018). An expectancy-value-cost approach in predicting adolescent students' academic motivation and achievement. Contemporary Educational Psychology, 54, 139-152.

Kusuma , Y., Kusuma , H. E., Tampubolon, A. C., \& Aryanti, T. (2018). Pengaruh Kualitas Lingkungan dan Motivasi pada Kinerja Akademik Siswa SMA. Jurnal RUAS, 16(2), 28-41.

Li, J., Deng, M., Wang, X., \& Tang, Y. (2018). Teachers' and Parents' Autonomy Support and Psychological Control Perceived in Junior-High School: Extending the DualProcess Model of Self- Determination Theory. Learning and Individual Differences, 68, 20-29. https://doi.org/10.1016/j.lindif.2018.09.00

Luthans, K. W., Luthans, B. C., \& Chaffin, T. D. (2019). Refining grit in academic performance: The mediational role of 
psychological capital. Journal of Management Education, 43(1), 35-61.

Mageau, G. A., Ranger, F., Joussemet, M., Koestner, R., Moreau, E., \& Forest, J. (2015). Validation of the Perceived Parental Autonomy Support Scale ( PPASS ). Canadian Journal of Behavioural Science, 47(3), 251-262.

Marbell, K. N., \& Grolnick, W. S. (2013). Correlates of parental control and autonomy support in an interdependent culture: A look at Ghana. Motivation and Emotion, 37(1), 79-92. https://doi.org/10.1007/s11031-012-9289-2

Martin, N., Kelly, N., \& Terry, P. (2018). A framework for self-determination in massive open online courses: Design for autonomy, competence, and relatedness. Australasian Journal of Educational Technology, 34(2).

Pierre, K. M., Grolnick, W. S., Stewart, A. L., \& Helmer, J. R. (2017). Parental Autonomy Support in Two Cultures: The Moderating Effects of Adolescents' Self-Construals. Child Development, 00(0), 1-21.

Power, K., \& Goodnough, K. (2019). Fostering teachers' autonomous motivation during professional learning: a self-determination theory perspective. Teaching Education, 30(3), 278-298.

Riany, Y. E., Meredith, P., \& Cuskelly, M. (2016). Understanding the Influence of Traditional Cultural Values on Indonesian Parenting. Marriage \& Family Review. https://doi.org/10.1080/01494929.2016.11 57561

Ryan, R. M., \& Connell, J. P. (1989). Perceived Locus of Causality and Internalization: Examining Reasons for Acting in Two Domains. Journal of Personality and Social Psychology, 57(5), 749-761.

Won, S., \& Yu, S. L. (2018). Relations of Perceived Parental Autonomy Support and Control with Adolescents' Academic Time Management and Procrastination. Learning and Individual Differences, 61, 205-216.

Zhang, J., \& Lynch, R. (2018). The relationship between primary 5 and 6 students' perceptions of parental encouragement and their academic achievement in Mandarin learning at an international school, Bangkok. Scholar: Human Sciences, 9(2), 243. 